
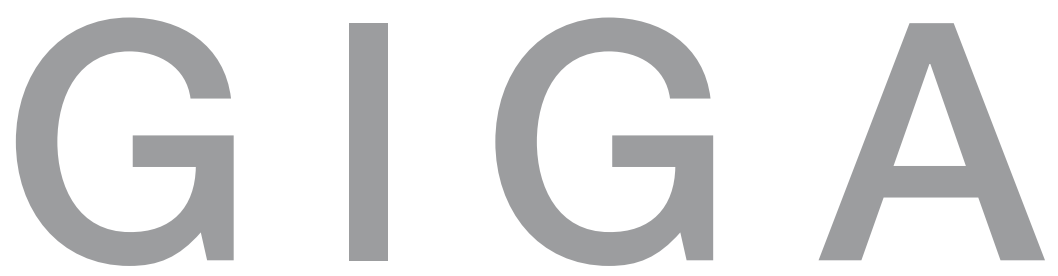

Working

German

Institute of Global and Area Studies Papers

Leibniz-Institut für Globale und Regionale Studien

GIGA Research Unit:

Institute of Latin American Studies

Why Reform Fails:

The 'Politics of Policies' in

Costa Rican Telecommunications Liberalization

Bert Hoffmann

$\mathbf{N}^{\circ} 47$

April 2007 


\section{GIGA Working Papers}

Edited by GIGA German Institute of Global and Area Studies / Leibniz-Institut für Globale und Regionale Studien.

The Working Paper Series serves to disseminate the research results of work in progress prior to publication to encourage the exchange of ideas and academic debate. An objective of the series is to get the findings out quickly, even if the presentations are less than fully polished. Inclusion of a paper in the Working Paper Series does not constitute publication and should not limit publication in any other venue. Copyright remains with the authors. When Working Papers are eventually accepted by or published in a journal or book, the correct citation reference and, if possible, the corresponding link will then be included in the Working Papers website at:

www.giga-hamburg.de/workingpapers.

GIGA research unit responsible for this issue: Institute of Latin American Studies

Editor of the GIGA Working Paper Series: Bert Hoffmann <hoffmann@giga-hamburg.de> Copyright for this issue: (C) Bert Hoffmann

Editorial assistant and production: Verena Kohler and Vera Rathje

All GIGA Working Papers are available online and free of charge at the website: www.giga-hamburg.de/workingpapers. Working Papers can also be ordered in print. For production and mailing a cover fee of $€ 5$ is charged. For orders or any requests please contact:

E-mail: workingpapers@giga-hamburg.de

Phone: ++49 (0)40 - 42825548

GIGA German Institute of Global and Area Studies /

Leibniz-Institut für Globale und Regionale Studien

Neuer Jungfernstieg 21

20354 Hamburg

Germany

E-mail: info@giga-hamburg.de

Website: www.giga-hamburg.de 


\title{
Why Reform Fails: The 'Politics of Policies' in Costa Rican Telecommunications Liberalization
}

\begin{abstract}
As the 'Washington Consensus' reforms are losing momentum in Latin America, the InterAmerican Development Bank (IDB) is calling for shifting the focus from the content of policy choices to the political process of their implementation. As this paper studies the paradigmatic case of telecommunications reform in Costa Rica it underscores the importance of these 'politics of policies'. The analysis finds, however, that the failure of repeated liberalization initiatives was not only due to policy-makers' errors in steering the project through 'the messy world of politics' (IDB); instead, as liberalization remained unpopular, policy content indeed mattered, and only the interaction of both explains the outcome. Particular attention is drawn to the political feed-back effects, as the failed reform, precisely because it had been backed by bi-partisan support, became a catalyst for the disintegration of the country's long-standing two-party system.
\end{abstract}

JEL classification: $\quad$ E61, E65, H42, L33, L96, 054

Key words: Liberalization, privatization, telecommunications, public enterprises, Costa Rica, development model, Inter-American Development Bank

\section{Bert Hoffmann}

is a political scientist and Senior Researcher at the GIGA Institute of Latin American Studies. Contact: hoffmann@giga-hamburg.de, website: http://staff.giga-hamburg.de/hoffmann. 


\section{Zusammenfassung}

\section{Warum Reform scheitert: Die „Politics of Policies“ der Liberalisierung des Telekom- munikationssektors in Costa Rica}

In dem Maße, in dem die mit dem „Washington Consensus“ verbundenen Reformen in Lateinamerika ins Stocken geraten sind, plädiert die Inter-American Development Bank (IDB) für eine stärkere Berücksichtigung nicht nur der Politikinhalte (policies), sondern auch des politischen Prozesses von deren Umsetzung (politics). Die vorliegende Untersuchung zum paradigmatischen Fall der Reform des Telekommunikationssektors in Costa Rica unterstreicht die Bedeutung dieser „politics of policies“. Sie zeigt allerdings auch, dass Ursache für das Scheiten wiederholter Liberalisierungsinitiativen nicht nur Fehler der Politiker sind, das Vorhaben durch „die unordentliche Welt der politics“ (IDB) zu steuern. Die breite gesellschaftliche Opposition gegen den Liberalisierungskurs bleibt. Nur die Interaktion von beiden, politics und policies, erklärt Verlauf und Ergebnis der Reform. Besonderes Augenmerk widmet die Studie den politischen Rückwirkungen der gescheiterten Reform: Sie wurde, just weil sie von beiden etablierten Parteien unterstützt wurde, zum Katalysator für den Zerfall des seit Jahrzehnten etablierten Zweiparteiensystems des Landes. 


\title{
Why Reform Fails: \\ The 'Politics of Policies' in \\ Costa Rican Telecommunications Liberalization
}

\author{
Bert Hoffmann
}

\section{Article Outline}

1. Introduction

2. The Transformation of the Telecommunications Regime in Latin America

3. Socially Inclusive Telecommunications Regime in the Third World: The Costa Rican Model

4. Liberalizing Telecommunications: The Politics of Reform Failure

5. Lessons Learned? The Political Feed-back Effects of the Liberalization Bill

6. Conclusions

\section{Introduction}

Debating different policy choices and weighing their pros and cons has been a classic activity of practitioners and academics alike. On all thinkable subjects there are people engaged in designing and recommending what they see as ideal policies. At times these go hand in hand with like-minded policy choices in other fields and galvanize into overarching paradigms for political, economic or social change.

One particularly influential example of such policy design is the paradigm of economic liberalization and deregulation that became dominant in Latin America in the 1980s and all through the 1990s. In what came to be known as the 'Washington Consensus' (Williamson 1990), a set of policy measures towards market-oriented reforms in Latin America was spelt out as recommendations shared by the key Washington-based international actors, namely 
the IMF, World Bank, and the U.S. government. Prominently among this 'standard reform package' figured the call for privatization of state enterprises and the abolition of regulations that were thought to impede market entry or restrict economic competition.

While the liberalization paradigm swept the continent and largely dismantled the economic structures of the more state interventionist development model that preceded it, by now some disillusion has set in. Economic results are not all that was hoped for, and social polarization has increased, rather than decreased. While according to the mainstream of Washington Consensus proponents liberalizing reforms should go hand in hand with good governance and better economic performance and should hence improve electoral performance, current trends signal rather the opposite. Opinion polls as well as social manifestations show growing discontent with the established political elites in numerous countries, and critics of the liberalization agenda are finding a growing following. In Venezuela, Bolivia and Ecuador this led to electoral victories of candidates promising profound social change and a reversal of liberalizing policies. The pendulum in the public perception and political viability of liberalization, 'this latest project of modernity' (Whitehead 2006: 194) the continent's elites embraced, seems to be swinging back.

Also within the Washington-based international financial institutions (IFIs) some revision has begun. Among these, the 2006 report of the Inter-American Development Bank (IDB) stands out as it focuses - so its title - on 'The Politics of Policies' (IDB 2005). The report's key argument is that a policy design of one-size-fits-all prescriptions is an excessively technocratic approach; instead the authors' premise is that 'the processes of discussing, approving, and implementing policies may be at least as important as the specific content of the policies themselves' (ibid: 3 ).

The present paper will undertake a case study of a core element of the reform agenda, the liberalization of state-run telecommunications, to analyze these 'politics of policies' and their implications. However, while the IDB report essentially looks at this process from the policy-makers' perspectives, we do so from a broader analytical angle. Not only can there be an overly technocratic approach to policy formulation but also to the analysis of the politics of reform, if it understands these as a mere question of political engineering. In contrast, this study will re-link the process dynamics of policy reform to its content, in which the liberalization of the public telecommunications monopoly needs to be seen as part of a broader economic paradigm shift.

The particular case under scrutiny merits a word of explanation. For half a century, the political and ideological importance of the 'Costa Rican model' has far outweighed the limited economic significance of this small Central American country with a population of only four million. However, in many ways the country can serve as a paradigmatic case. With its sta- 
ble political democracy and its high human development standards, Costa Rica has been Latin America's 'showcase democracy' and a model for socially inclusive capitalist development in a resource-poor Third World country, often termed 'social-democratic' (e.g. Wilson 1998) or 'mixed model' (e.g. Mesa-Lago 2000). This characterization corresponds with a widespread perception in the country itself. Modern Costa Rica's 'founding father' José 'Pepe' Figueres Ferrer once put it: 'Costa Rica is not a country. (...) It is a project. It is an experiment' (cited in: Ernst/Schmidt 1986: 58).

Following this introduction, the paper will proceed as follows: Section 2 develops an analytical framework around the concept of telecommunications regime, which situates the case study in a broader comparative perspective. It sketches the three ideal types most relevant to this study, and review the emergence of the liberalized telecommunications regime in Latin America in the 1990s. We will then move to the Costa Rican case study. Section 3 outlines the cornerstones of the Costa Rican development model and shows how these translated into a telecommunications regime that was far more inclusive than the continent's typical mould. Section 4 then brings this analysis to bear in the empirical study of the liberalization drive which culminated in the approval of a telecommunications reform law in 2000, only to be followed by its retraction after large-scale social protests. If this failure of policy implementation highlights the gap between intra-elite arrangements and public support, section 5 will explore the reform initiative's feed-back effects on the political actors themselves, as it became a catalyst for the disintegration of the country's long-established two-party system. This political fallout becomes all the more relevant as the issue of telecom liberalization has resurfaced on the national political agenda as part of the CAFTA free trade agreement, which the current government of Óscar Arias is committed to push forward. The paper concludes by stressing that the failure of reform was not only due to tactical errors in steering the project through 'the messy world of politics' (IDB 2005: 4) but that indeed policy content mattered, and that only the interaction of both explains the outcome.

\section{The Transformation of the Telecommunications Regime in Latin America}

The analytical framework of this paper centers aroung a concept of telecommunications regime that binds together the specific configuration of economic, social and political actors and regulatory frameworks - including structures of ownership and market, pricing schemes and patterns of diffusion and consumption in any given country or region. From this we can draw clearly distinguishable patterns, which allows to situate the analysis of any particular case in a broader comparative perspective. 
In the following we sketch three different ideal types of telecommunications regimes, which provide the conceptual backdrop for the following analysis: The state-centered First World telecommunications regime typical of the industrialized countries up to the 1970s and '80s; the traditional state-centered Third World telecommunications regime; and the liberalized telecommunications regime that became such a forceful paradigm in the 1980 and ' 90 s, challenging both of the above and often replacing them.

This approach links the telecommunications sector ${ }^{i}$ to the general economic and social development patterns. In the context of the state-centered First World regime, telecommunications were regarded as a 'natural monopoly': an industry that had such extraordinarily high sunk investments, with only long-term amortization, and such a high degree of economies of scale and scope, that it was considered too costly to have competing providers investing in duplicate infrastructure. Classic liberal economic theory long accepted that, given the specifics of the network-based service offered, any single monopoly provider could offer services more cheaply and better than competing providers. In consequence, public monopolies took charge of telecommunications, usually under the Ministries of Posts, Telegraphs and Telephones (PTTs) ${ }^{\mathrm{ii}}$. Characteristic of this type of telecommunications regime was the state's commitment to achieve universal service; as a consequence, investment focused on the continuous expansion of the network with the goal of providing residential telephone main lines for every household. The pricing scheme generally was based on crosssubsidies from long-distance to local calls, from business to residential users, and from urban to rural areas.

For Third World countries embarking on industrialization strategies in the 1950s, as particularly the Latin American countries did, modernization theory postulated the OECD countries as their 'role model' for development. However, just as much as the overall modernization policies led to only deformed copies of the First World models, particularly failing to provide an economically sustainable scheme of inclusive social integration, the regulatory framework of the social welfare state, and stable political democracy, so did the telecommunications regime result in a 'halved' version. It copied parts of the First World model - public monopolies, cross-subsidization schemes -, but failed on others, namely to extend the telephone network to include the citizenry at large or to bridge the gap between urban and rural areas.

In Africa and Asia, most governments nationalized telecommunications in the wake of independence. In the Latin American countries, independent since the early $19^{\text {th }}$ century, it was in the course of the 'developmentalist' projects of the post-WWII period, that governments turned foreign-owned telecommunications companies into state-run monopolies. 
Telecommunications became widely regarded as an integral part of the nation's public infrastructure, and nationalization as part of the realization of national sovereignty.

National development plans, however, did not assign telecommunications investments first priority. Instead, the state monopoly company proved to be a profitable cash-cow, chronically transferring as much as 30 to 40 per cent of its revenues to the treasury (Saunders et al. 1994: 34). As a consequence, the public telecommunications companies suffered a chronic capital drain that greatly reduced their capacity to invest, expand and innovate. Diffusion and quality of telephone networks in the Third World generally remained poor. Year-long waiting lists for main line telephone installation became the landmark illustration of the deficiencies of state-run monopolies under these conditions. Characteristically, the statecentered Third World telecommunications regime maintained a strong bias geographically, in favor of the urban areas, and socially, in favor of the upper and middle classes (e.g. Clippinger 1976). The goal of 'universal service' was not even seriously put on the agenda. In 1984, the International Telecommunication Union's Maitland Commission concluded that 'in most developing countries, the telecommunication system is not adequate even to sustain essential services' (ITU 1984).

In the First World, it was the U.S. government that laid the cornerstone of a new, liberalized telecommunications regime when it broke up the AT\&T monopoly in 1984. In Latin America, telecommunications liberalization came in the wake of the foreign debt crisis and the structural adjustment programs negotiated with the IMF and the World Bank (ITU 1991). However, initial steps were more timid than in other sectors. The continent-wide 'wave' of telecom liberalization did not fully hit Latin America until the beginning of the 1990s. The driving force for divestiture of the state-owned monopolies was less a policy choice weighing the pros and cons of each model, but rather the fact that 'a decade of economic crises during the 1980s left many Latin governments strapped for cash and unable to resist the demands of financial institutions', as the ITU, which had a key role in the international promotion of the liberalization paradigm, puts it (ibid: 2).iii As a result, governments rather than national business became the key force pushing for telecommunication privatization. ${ }^{\text {iv }}$ It thus followed the traditional Latin American pattern of reform 'from above and without' (Whitehead 2006: 165).

The shift to the liberalized telecommunications regime came in different forms. In some cases it was clear-cut privatization through the sale of the state-owned companies; in others it was a process of exposing the state carrier to private sector competition. These processes are neither identical nor always concomitant. To the contrary, as the ITU had to note in looking back,that in most Latin American countries 'privatization came hand in hand with a lack of competition in basic services (...). What resulted (...) was merely the replacement of a pub- 
lic monopoly by a private one' (ITU 2000: 2f.) - an outcome described as the 'typical Latin American model of privatization' (Raventos 1998: 1)v.

Being a market-driven model, the liberalized telecommunications regime's intrinsic focus is on consumer demand endowed with purchasing power rather than on developmental or social goals. While waiting lists for telephone installation disappeared, prices became the key to access. Here, the elimination of cross-subsidies and the 'rebalancing' of tariffs led to a considerable rise in the rates for domestic calls. Again, the conclusion drawn by the ITU (2000: 3 ) is sobering:

The glitter of privatization has faded. (...) Latin America still faces the hard fact that not much more than one-third of the region's households have a fixed telephone. Even though a large proportion of the population is still without a phone, according to conventional statistics, there is hardly any unmet demand for telecommunications services in the region. The main reason for this is that local access prices (monthly subscription) have generally risen, excluding a great part of the population from the market.

While in hindsight the 'glitter of liberalization' has faded, the wave of telecommunications reform in Latin America in the 1990s had found, on the whole, only limited opposition. In the 'politics of policies' of opening up the sector, it had been of key importance that the proponents of liberalization could insistently point to the poor performance of the public monopoly carrier in the typical state-centered telecommunications regime in the Third World. If we now turn to the Costa Rican case, we will see that here a more inclusive development model went hand in hand with a more inclusive telecommunications regime; and that where the public carrier lived much more up to its social and developmental function, also the 'politics of policies' of its liberalization took a strikingly different course.

\section{Socially Inclusive Telecommunications Regime in the Third World: The Costa Ri- can Model}

Costa Rica won international reputation as a model country as much by its extraordinary political stability as by its far above average performance in nearly all social indicators, compared to other Third World countries (cf. UNDP 2006). Public health and educational services are accessible for the population at large, and the average life expectancy of 78.3 years is not only higher than in the rest of Latin America, but also above that of nations like Denmark or Portugal (ibid: 283). These achievements are all the more remarkable as Costa Rica is a resource-poor country with only a medium level of GDP/capita and a relatively large share of the population living in rural areas. 
The underlying political structures go back to 1948, when a governing board under the leadership of José 'Pepe' Figueres, which emerged victorious from a short civil war, laid the political and economic foundations of a socio-economic model often termed 'social-democratic' (Wilson 1988). Following the 'developmentalist' ideas of the UN's Economic Commission on Latin America, CEPAL, the state took over a central role in the economy, and an importsubstituting industry (ISI) was established, primarily in consumer products, light industry and agro-industrial sectors (Bulmer-Thomas 1987: 185-191). Of no less importance for Costa Rica's social cohesion, however, were a series of structural reforms to support small and medium farmers, including a gradual agrarian reform and the establishment of public institutions for technical support and price regulation. These policies ensured the persistence of a relatively broad rural middle class that has been a key factor for the of Costa Rican society (Seligson 1984).

On the political-institutional side, the most spectacular measure was the abolition of the country's military, enshrined in the Constitution of 1949. This step was essential for the long-run viability of Figueres' reform project, since it eliminated precisely that institution to which anti-reformist elements across Latin America resorted when they felt their interests threatened. Moreover, it paved the way for electoral, civilian rule, which for more than half a century has never been seriously disrupted by violence or electoral fraud. A stable twoparty-system emerged. Despite a rather regular pattern of alternation in power, the Partido Liberación Nacional (PLN), formed in 1951 by Figueres, dominated the political agenda even when its opponents held the presidency. The rival second party existed in different constellations and under different names, but since 1983 as Partido Unidad Social Cristiana (PUSC). While being moderately more conservative, it shared the basic consensus on the country's overall socio-economic model.

A centerpiece amongst the model's 'founding institutions' was the Costa Rican Electricity Institute (Instituto Costarricense de Electricidad, ICE), created in 1949. The ICE not only was the state monopoly company for energy generation and electricity supply, but also for the nation's telecommunications system - a nearly unique combination internationally. It provided the energy resources for the state-led development and industrialization plans that started in the 1950s; and it fulfilled a central social function by investing great sums in a continuous push for a geographically and socially inclusive system of electricity provision. As electricity was a key concern for all sectors of society, the ICE became probably the most emblematic institution of the Costa Rican development model.

Although telecommunications for a long time appeared as the smaller sister of ICE's electricity activities, here, too, the institution made great strides in the nationwide extension of the network, following the same pattern of geographical and social inclusion as the power grid 
(ICE 1997b). The ICE subsidized rates for telephone access and domestic calls, and engaged in outreach programs for rural areas, including the installation of public call offices on a concessionary basis in small towns and villages, forerunners of today's internet cafés. In contrast to the prevailing approach in most of the Third World, the Costa Rican model saw telecommunications not as a luxury item for the urban elites, but as a core function of national integration and development. As a result, Costa Rica enjoys one of the densest and socially most balanced telephone networks of all developing countries (ITU 2006). The country's telecommunications regime thus greatly departs from the typical Third World mould. In line with its exceptional overall development model, the diffusion and access patterns of telecommunications instead resemble those of the inclusive state-centered telecommunications regime of the First World, though implemented in the conditions of a poor country. As a consequence, unlike other Third World countries, where the chronic deficiencies of the telephone system provided a strong argument for the dismantling of the state monopoly, in Costa Rica even outspoken advocates of liberalization like Tacsan (2001) cannot but pay respect to the historic achievements of the ICE:

No doubt, it accomplished an extraordinary job of networking the whole country with telephone lines (...). In Costa Rica, one out of five persons has a telephone line which means that virtually every house owns one. The difference is certainly radical if compared to the neighbouring Central American countries where one out of 20 persons has access to a phone line. The data is significant in the sense that it shows the excellent performance of ICE in the provision of basic line communication in Costa Rica.

Similarly, Ricardo Monge, the coordinator of the telecommunications liberalization bill in 2000 that was designed to open up the sector (see below), underscores the extraordinary standing the state-owned energy and telecommunications company enjoys: 'The ICE is the institution par excellence for Costa Rican national pride' ${ }^{\text {vi }}$

\section{Liberalizing Telecommunications: The Politics of Reform Failure}

The drive for economic liberalization policies in Costa Rica began, as elsewhere, in the wake of the foreign debt crisis. ${ }^{\text {vii }}$ It was a PLN government that signed the first stabilization agreement with the IMF in 1982, which marked the beginning of a long process of structural adjustment programs. In line with the 'standard recipes' of the Washington-based IFIs, these encompassed the reduction of state expenditures to lower the budget deficit, the reduction of subsidies, the adoption of a strategy of export-led growth, and the privatization of stateowned enterprises. 
Nevertheless, these policies retained a more gradual and heterodox approach than in other countries. If this was partly due to the political-institutional structures inclined to consensus and negotiated compromise, externally Costa Rica benefited from its role as Washington's prime ideological counter-model against Central America's left-wing revolutionaries. Direct U.S. aid flows increased greatly, covering more than 50 per cent of Costa Rica's current account deficit between 1982 and 1985 (Fürst 1990: 190). In Costa Rica U.S. policy was keen to avoid social destabilization due to excessive reform pressure, resulting in the anomaly of an adjustment program accompanied by an actual increase in real social expenditures (MesaLago 2000: 496).

For the political system it was crucially important that it were PLN governments, the administrations of Luis Alberto Monge (1982-1986) and Óscar Arias (1986-1990), which steered this shift away from Costa Rica's traditional development model and set the course for a gradual, socially cushioned, yet continuous adoption of liberalization policies (Wilson 1994). As the study of Seligson (2002) shows, this went hand in hand with a gradual decline in public support for the established party system, which, however did not translate into open challenges to the political establishment in the 1980s and 90s. The PLN did suffer internal tensions, though. Most notably, Óscar Arias' planning minister, Otton Solís, quit his office in open conflict with Arias over the government's embrace of liberalization (not yet knowing that 18 years later they would face each other in hard-fought Presidential elections).

The pressures on state finances and the overall turn to liberalization did not bypass the country's telecommunications sector. If in the following we track the 'politics of policies' of liberalizing Costa Rican telecommunications ${ }^{\text {viii, }}$ it is fair to start out with the Monge administration (1982-86). Although it did not include the ICE in any privatization scheme, it accelerated the drain of financial resources from the company to cover the growing public deficit. As a consequence, the company began to lose the capacity for the large-scale investments needed for the digitization and modernization of its infrastructure.

It was the following government of Óscar Arias (1986-1990) that launched the first plan to privatize services offered by the ICE. In line with the gradualism of Costa Rican politics, the plan proposed the partial sale of company shares and the participation of private companies through strategic alliances. Protests from the ICE's unions and other groups of the PLN's social base quickly halted this initiative. In a different line, the Arias government attempted to open up the state monopoly for mobile telephony, issuing a license for the U.S. company Millicom. However, Costa Rica's audit office, the Contraloría General de la República, stepped in to block the arrangement after the ICE's unions began a formal law suit against the license. Eventually Costa Rica's constitutional chamber of the Supreme Court, the Sala Cuarta, declared the deal unconstitutional. ${ }^{\text {ix }}$ 
In 1994, again a PLN government under President José María Figueres Olson - the son of 'founding father' José 'Pepe' Figueres - set up a commission headed by former Central Bank President Eduardo Lizano, the country's most vocal advocate of liberalization, to address the state's domestic debt. The commission recommended the sale of state assets, including the state electricity and telecommunications monopoly (Lizano 1997: 59). This, however, triggered immediate protests from so many sides, that Figueres shelved the commission's recommendations. Instead, he sought bi-partisan agreement on the overall course of liberalization which cristallyzed in the Figueres-Calderón pact, signed in 1995 by the incumbent President and his immediate predecessor. This pact became all the more symbolic as its signatories were the sons and political heirs precisely of those two leaders who had stood against each other in the Civil War of 1948 which had gaven birth to the 'Costa Rican model', José 'Pepe' Figueres Ferrer and Rafael Ángel Calderón Guardia, respectively.

Regarding telecommunications, the Figueres government turned to a project that, rather than pursuing privatization via the sale of the ICE, sought to leave the company in place but break up its monopoly by inviting private competition (Monge 2000: 289f). The project encompassed three bills that were jointly introduced in the National Assembly in September 1996: First, a new 'organic law' for the ICE that included the separation of the telecommunications and electricity sectors, which would operate as independent companies under the ICE, recast as a rather loose umbrella; second, a new law for the energy sector; and third, a new law for telecommunications. The telecommunications market was to be opened to private competition, with a gradualist schedule stretching over five years. However, these bills were introduced in the second half of Figueres' term, when the upcoming elections dominated the calculations of parliamentarians of both parties. As it was widely felt that the ICE liberalization would be unpopular, both parties opted to avoid conflict and to postpone the initiative for the time being (Monge 2000: 291).

After the 1998 elections, the newly elected President of Miguel Angel Rodríguez (PUSC) inherited the pending liberalization bills. He did present the electricity bill directly to the National Assembly, but - learning from past failures - prior to submitting the other two bills he called for a consultation process, the Foro de Concertación Nacional. This forum reached a partial agreement, which the government, business sectors and trade unions all signed. Although the PLN (arguing for more gradual liberalization) and the small left-wing party Fuerza Democrática denied their support, acceptance by unions was seen as a breakthrough towards the political viability of the project. On the basis of these accords, the government then introduced both bills into Parliament.

The telecom bill sped up the gradualist approach to liberalization, envisaging full competition in the sector as early as 2002. At the same time, it promised to continue the govern- 
ment's social commitment through the establishment of a universal access fund, FOSUTEL, and a new regulatory body, ARETEL. The fund would be financed from obligatory contributions from all companies operating on the telecom market, amounting to 15 per cent of their earnings in the first four years and 40 per cent for the following years.

When telecommunications reform initially hit Latin America, in a 'contagion effect' it rapidly spread from country to country. In his discussion of this type of 'wave theories' in the process of privatization Whitehead points out, that one way for this effect to reach its limit is when disillusion with the results of previous experiences sets in (Whitehead 2006: 187). Costa Rica is a perfect example for this. As a result of the 'politics of policies' described above, telecom liberalization had been postponed for so long, that the 'contagion effect' lost its power for the belated follower of the 'wave'. Rather to the contrary. Given the the network's broad diffusion of and ICE's low tariffs for subscription and domestic calls, proponents of liberalization could not promise much improvement on these anyway; but this now combined with the hindsight on the liberalization experiences in other Latin American countries which had led, as noted earlier, to often substantial rate increases for these services. The pro-liberalization campaign sought refuge by focusing criticism of the state monopoly on its shortcomings regarding mobile phones and the new digital information technologies. But for the majority of the population these were secondary issues; its much greater concern was the real accessibility of basic telephone service. And widespread sense of elite alienation and corruption crucially undermined the trust that the promised universal service fund would fulfil its function effectively, whereas the ICE's past record was seen as having proved by deeds its social commitment.

In the political arena, the refusal of the PLN and the left-wing Fuerza Democrática to sign the national consultation accord led to a new round of negotiations, as the governing PUSC did not have a parliamentary majority. The PUSC as much as the PLN pushed for rapid progress, since both wanted to finish with the issue before the next long pre-electoral period would hamper implementation. In consequence, they agreed to modify the Legislative Assembly's procedures to allow for a fast-track approach to the bill (cf. Asamblea Legislativa 2000), as well as to modify the bill on essentially two points: the time frame for the stepped opening of the telecommunications market to competition was expended; and the agreement reached in the consultation forum regarding the composition of the new regulatory body's board was thrown out. Instead of the agreed upon seven members - two from government, two from business organizations, two from trade unions and one from the national commission for the protection of consumer rights - the new version proposed a board of five members, all of which appointed by the government. The result was that the trade unions protested their exclusion and withdrew their support for the bill. 
Another decision by the leaders of the two dominant parties, bent on accelerating the process, proved to be as relevant for the bill's eventual failure: The decision to bundle the three separate bills - the law restructuring the ICE, the law on energy and the law on telecommunications - into a single project (which the media quickly labelled the Combo del ICE in allusion to the package deals offered by fast-food restaurants). ${ }^{\times}$The political rationale was that without such a package deal, the three projects could not pass before the end of parliamentary sessions in April 2000, threatening to have the issue stretching into pre-election times. In terms of parliamentary process, leadership agreements, fast-track proceedings and bill combination achieved their aim. On March 20, 2000, the Legislative Assembly passed the comprehensive reform law with ample majority: all PUSC and all but three PLN representatives voted in favor, while only the three PLN dissidents and the seven representatives of the small parties voted against. ${ }^{x i}$ Liberalization had become law. But not for long.

The passage of the Combo del ICE law by the Legislative Assembly proved to be a pyrrhic victory. The gradual erosion of public support for the established parties, a tendency Seligson (2002) has diagnosed since the 1980s, now broke out openly. The party leaderships had limited their 'politics of policies' calculations to the political, media and business elites, while the popular perception of this project only entered calculations in so far as the decision was to be kept at sufficient distance from election day. By brushing aside the consultation accords in the National Assembly negotiations, the bi-partisan agreement not only ruined what had been the government's greatest success - union support for the liberalization bill - but to a broader audience it confirmed widespread negative views of the arrogance and detachedness of 'the political class'. And while the combination of the three laws into one package deal had been instrumental to accelerate the parliamentary process, it now proved as instrumental for rallying very diverse social forces into a heterogeneous alliance of opposition to the bill.

The least surprising opposition came from the unions of the ICE who feared the loss of employment and benefits. Other unions of public employees quickly closed ranks, fearing similar initiatives in their own sector if the country's liberalization course were pushed forward. Unions from that of the teachers to that of the oil workers staged solidarity strikes and called for members to participate in the anti-Combo-demonstrations.

These mobilizations were soon joined by the university students. This needs explanation as these mainly came from upper or middle sectors of society, and for them the 'heroic' days of the ICE's role in national development could have been distant history. In addition, since the students have disproportionately high interest in Internet use, they seemed a prime target group for the argument that the state monopoly blocked the dynamic development of the new information technologies. However, the majority of the students did not perceive the 
Combo law as a means to improve these services but instead as part and parcel of a broader agenda of liberalization which they opposed. This combined with a wide-spread disenchantment with the political establishment, so that the Combo del ICE law became the case to articulate dissatisfaction that went far beyond the telecommunications issues in a narrow sense that it involved. Following the students' demonstrations and teacher strikes, secondary students also joined the street protests. Practically all the ecological associations in the country joined against the Combo del ICE, particularly galvanized by article 119 of the law that facilitated the building of new hydroelectric plants in nature reserves by private companies.

Another unexpected, but highly important, sector participating in the protests against the liberalization law was the countries' peasantry. Pressured by the fall of world market prices for a number of major agricultural products, peasant organizations across the country had been mobilizing their bases to demand increased government support. These rural protests rapidly fused with the anti-Combo demonstrations in the cities. Particularly in the countryside, appreciation of the ICE's role as a cherished institution of development and social integration was very much present; and it was in the rural areas, where the privatization of services raised particularly strong fears of losing the ICE's developmental commitment. The peasants' principal form of protest was the blocking of overland roads, a measure that greatly disrupted transportation and economic activities, exerting a strong pressure on the government to act.

Among the political parties, the small left-wing Fuerza Democrática gained national profile as a political force that supported the street protests and voiced their concerns in the formal political arena. However, the 'defense of the ICE' also drew support from dissidents in the dominant parties. In the case of the PLN, Óscar Arias' former planning minister Ottón Solís led the dissidents. After quitting office in the Arias administration in the 1980s, he had remained a loyal party member and even parliamentarian; but now he formally broke with the

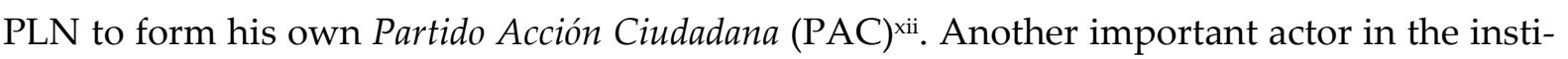
tutional political arena was the country's ombudswoman (Defensora de los Habitantes), Sandra Piszk, who spoke out energetically against the Combo law in the name of the politically unorganized 'silent majority'.

In fact, while it was important for the protest coalition that it could unite heterogeneous social forces under a common goal, it was even more vital for its success that it could count on broad, though less visible support from the population at large. Opinion polls leave little doubt that the country's 'silent majority' viewed the demonstrations favorably. A survey conducted in May 2000 shows a solid two-thirds majority of those interviewed supporting the protests (Unimer-La Nación 2000). More telling still is that no less than 86.9 per cent 
agree to the statement that 'protests organized by some groups received spontaneous support by the population' (ibid). The poll also confirms the weight of the widespread disenchantment with the 'political class' as no less than 93.7 per cent of the interviewed agree that 'the protests were a message to the PLN and PUSC that the Costa Ricans are tired of what they have done to the country' (ibid).

The scope and aggressiveness of the anti-Combo protests reached a level of conflict unknown in the country's recent history. When after two weeks the social unrest showed no signs of subsiding, the government decided to withdraw the law on April 3, 2000xiii. This decision needs explanation, as the government had staked a lot, nationally and internationally, on the reform. In fact, in the face of the street protests President Miguel Angel Rodríguez at first remained committed to pushing the law through 'no matter what'; it was additional pressure from three different directions that finally forced him to give up ${ }^{x i v}$.

One rather unexpected source of increasing pressure were business interests. The road blockades not only affected agricultural products, which rotted due to lack of transport, but also companies such as Intel, whose Costa Rica-based microprocessor plant suffered the disruption of its electricity supply and the blocked access to the airport. While the private sector largely supported the liberalization law in principle, their more immediate concern was a return to normal business conditions. And if the government could not restore order by force, business spokesmen urged to do so by backing down ${ }^{\mathrm{xv}}$.

Pressure also came from the President's party itself. When the protests did not, as expected, subside after the passing of the law, fears grew that the conflict might jeopardize the party's long-term political perspectives. Delegates and party members calculated that the longer the government kept to its unpopular project, the deeper the rift between the party and the electorate would be.

The third element pressuring the government into retreat came from the judiciary system. About ten days after the law's passing, the word began to spread that the country's highest constitutional court, the Sala Cuarta, would suspend the law on the grounds of procedural mistakes. At this point, even for the government's hardliners it no longer made sense to stand by the bill. The question could not be answered anymore, why the government should keep on fighting at a truly high political price when two weeks later the Sala Cuarta would overrule the law anyway. Indeed the constitutional court revoked the law package on April18, less than a month after it was passed (Sala Constitucional de la Corte Suprema de Justicia 2000).

'Defending the ICE!' as the main slogan of the anti-Combo coalition went, was about more than just a specific institution; it almost took on the form of a plebescite 'in defense of the welfare state' (Bull 2005). The reform proposal was, as analyzed above, embedded in an 
overarching paradigmatic shift towards a different development model, and the protests and reactions it triggered indeed took it for nothing less.

\section{Lessons Learned? The Political Feed-back Effects of the Liberalization Bill}

The IDB report on the 'Politics of Policies' cited in the introduction puts a special emphasis on the argument, that 'policy reforms often have feedback effects on the policymaking game' and that these should be given special consideration when opting for policy choices (IDB 2005: 8). There hardly could be a clearer case for this than thetelecom liberalization initiatives in Costa Rica, as the struggle over the Combo bill became a catalyst for the collapse of the traditional two-party system.

An opinion poll a few months after the ICE conflict showed a strong continuation of the trends diagnosed by Seligson (2002): a clear majority of Costa Ricans supported democracy as their preferred political system, but at the same time an equally clear majority showed discontent with 'the politicians,' sharply criticized the major parties and felt ill-represented by them. ${ }^{\text {xvi }}$ Opposition to the liberalization bill became a channel for the articulation of discontent that until then had found only insufficient voice in the political arena. This crystallized in the 2002 Presidential elections when PLN and PUSC together fell to 63 per cent of the vote, after obtaining 92 per cent in the previous five elections (Lehoucq 2005: 142). PLN dissident Otton Solís, who had broken with the party over the ICE bill, ran as candidate of his own improvised party, the Partido Acción Ciudadana, PAC (Citizen Action Party). Campaigning on a platform that could be summarized as 'Old PLN,' opposing the liberalization course taken since 1982 (Solís 2001), he virtually split the PLN vote, gaining a stunning 26.2 per cent.

The PUSC managed to escape the electorate's punishing vote essentially because its party leadership suffered defeat already well before Election Day. The candidate favored by the PUSC leaders lost the party's primaries to a complete outsider, the popular TV commentator Abel Pacheco. It was precisely Pacheco's distance from the party apparatus that gave him credibility and that became crucial for his impressive ability to capitalize on the discontent with the government while maintaining most of the PUSC's traditional vote, thus winning the Presidency. In Congress, the end of bi-partidism b ecame evident, as parties not aligned with the PLN or the PUSC were holding 37 per cent of the seats.

As to telecommunications, after the political disaster of the Combo law, the majority parties quickly distanced themselves from the project. The government party's parliamentary leader, Eliseo Vargas, declared the break-up of the monopoly to be no longer an option, 
since 'there are political and social realities we have to respect' (La Nación, 27 Oct 2000). He summed up the 'lessons learned' as follows:

The Costa Rican populace has been very clear, and it has said 'No' to the opening up of telecommunications and electricity. (...) We are no masochists, we will not insist on something to which 'No' has been said. Any such rumors are malicious. Let me be very clear about this: The Combo has died, and it has died forever (El Semanario, 2001: 7).

In the following weeks, the government signalled a change of course. First to disappear was the alarmist discourse that had linked the nation's fate to the passing of the ICE law. Instead, the government started what it regarded as a 'second best option': the modernization of the telecom sector under the state-monopoly of the ICE. The appointment of Guy de Téramond, the country's leading informatics professor and highly respected 'father of the Internet in Costa Rica', as the new Minister for Science and Technology, symbolically marked the government's commitment to invest in the new digital technologies. This was flanked by the launch of the 'Digital Agenda' program which included numerous state-led initiatives for infrastructure investments, diffusion of access, and the integration of the new technologies in public institutions, the education and health sectors, and in small and medium businesses

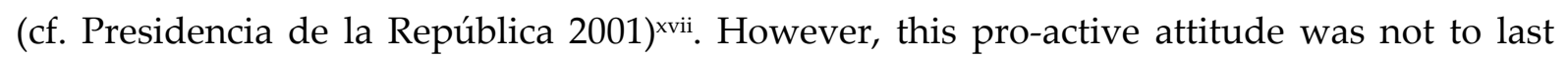
long. Guy de Téramond was replaced after only two years in office, and as early as in August 2002, the government returned to the policy of draining the ICE's resources, obliging it to contribute US\$13.5 million to the state budget (La Nación, September 26, 2002).

While most domestic political actors, still traumatized by the Combo experience, kept a low profile on the issue, in 2002 telecom liberalization forcefully returned on the Costa Rican agenda as part of the Central American Free Trade Agreement (CAFTA). CAFTA promises improved access for Central American products to the U.S. market in exchange for further opening the Central American economies to U.S. companies. While the initial draft included provisions to fully open the telecommunications sector to private competition, the Costa Rican government renegotiated this part. It conceded to opening Internet services, mobile telephony, and data-network services, but not the ICE's monopoly on main line telephony and electricity. On January 25, 2004, the Costa Rican government finalized negotiations with the USA and joined CAFTA - pending ratification by the U.S. Congress and Costa Rica's Legislative Assembly.

The Pacheco government was eager to point out that the agreement was not a 'Combo Reloaded'. Minister of Foreign Commerce, Alberto Trejos, argued that 'the ICE will not be adversely affected - it will be strengthened by a modern legislation and it maintains its monopoly in what it does best: the generation of electricity and the provision of main line te- 
lephony' (La Nación, January 28, 2004). However, the anti-Combo alliance felt that the government did 'insist on something to which »No« has been said'. In particular, critics point to the fact that the activities singled out for liberalization are those that generate much of the state company's revenues to maintain its socially and geographically inclusive pattern of mainline provision and low user tariffs (Fumero Paniagua 2004).

Moreover, with CAFTA telecom liberalization once again comes as a package deal. While the government unbundled the Combo bill, separating main line telephony and electricity from mobile telephony and Internet services, it explicitily embedded telecom liberalization in the even broader scheme of the free trade agreement. Again, this packaging helps heterogeneous social groups to join forces in opposition, CAFTA now taking the Combo's place of galvanizing protest in defense of the 'Costa Rican model'. President Pacheco became a staunch defendant of the CAFTA depicting the horror of sacrificing hundred thousands of jobs if CAFTA were not ratified (La Nación, January 29, 2004). However, while CAFTA was ratified in the USA, the Dominican Republic (for which it was rebaptized as 'DR-CAFTA') and all other Central American states in 2004 and 2005, the Costa Rican President, fearing renewed social unrest, decided to leave the task of taking it to the Legislative Assembly to his successor.

In the meantime, the political fallout reached new dimensions. Corruption scandals, most of which associated precisely with the telecommunications sector, shook the country ${ }^{x v i i i}$. In autumn of 2004, the Costa Rican public witnessed the spectacle of two former Presidents being arrested on corruption charges, and a third one come under investigation. In addition, President Pacheco himself got under fire for dubious campaign financing. By 2005 all hopes put on him by the electorate had dashed, and opinion polls showed him getting the poorest ratings of any Costa Rican president in decades (CID Gallup 2005).

On this background the 2006 Presidential elections came to mark a watershed, sealing the end of Costa Rica's traditional bipartidism (Huhn 2006). The governing party, PUSC, was virtually annihilated, falling to an incredible 3.5 per cent. The pro-establishment vote rallied around the PLN's candidate, former president and Nobel Peace price laureate Óscar Arias. But the political rise of the candidate critical of liberalization, Otton Solís, continued, obtaining a sensational 39.8 per cent of the vote and losing to Arias by a mere 1.1 percentage points.

Despite his self-confessed 'humbling' by the slim nature of his victory, Óscar Arias is determined to push ahead with the CAFTA agreement. While he does not have a parliamentary majority of his own, he may be able to muster majority support in the Legislative Assembly in alliance with the remaining PUSC delegates. If past experience is any indicator, it will be 
worth to carefully watch the political fall-out of this insistence on pursuing the course of economic liberalization.

\section{Conclusions}

It is a legitimate subject of study to discuss the pros and cons of specific policy designs. However, as the IDB's 2006 report rightly points out, such a comparative policy exercise will not suffice for explaining the policy outcomes and their real-world effects, if it does not consider adequately the dynamics of the policy-making process. If the report argues that 'the political process and the policymaking are inseparable' (IDB 2005: 4) and that 'to ignore the link between them when pursuing policy change may lead to failed reforms and dashed expectations' (ibid), the Costa Rican case is second to none in illustrating the validity of this argument.

At the same time, however, our analysis also shows the shortcomings of an overly technocratic understanding of the 'politics of policies'. The failure of reform was not only due to policy-makers' tactical errors in steering the project through 'the messy world of politics' (ibid). While we indeed identified a number of specific decisions that negatively affected the viability of the liberalization initiative, only a more holistic view can put these in proportion. This must take into account the specific historic trajectory of the country, as the support for policy change is likely to be the greater the more dissatisfied the citizenry is with the preceding state of things; and it must avoid an artificial separation of 'politics' and 'policies', as it is the content of policy choices that shapes the actors' responses to it.

In these regards the conceptual framework of the telecommunications regime and the different ideal types we established proved fruitful as they situate the specific reform project in the overarching economic and social transformation under way. Costa Rica's preliberalization telecommunications regime was one of the most socially inclusive to be found anywhere in the Third World. As a consequence, to most of the population the expected downsides of opening up the state monopoly outweighed its promises. Hence, it was indeed the content of policy, that was at the root of the protests against it. Moreover, widening the focus on the social and economic model in which the reform was embedded provides the key to understanding why the telecom bill of 2000 provoked a conflict that went far beyond an issue of sectorial policy choice but amounted to a virtual plebiscite on the country's development model.

The case study also highlights the feedback effects of policy reform (even if eventually aborted) on the political actors themselves. The bi-partisan agreement on the liberalization 
bill had secured a more than 80 per cent majority in parliament. It would have been a success case for a 'politics of policies'-minded reform process, if only it had indeed been backed by similar public support. While initially there was some outreach to civil society groups, in the end the citizenship entered into consideration only as a factor to be kept away from the decision-making process, as both parties joined forces to accelerate the legislative passing of the bill in order to keep sufficient distance between this and the next national elections.

The successful negotiation of the party elites turned out all the more counterproductive as it increased the popular sense of an alienated 'political class' that, instead of representing society's plural positions, closed ranks on a policy measure about whose unpopularity it was all too aware. On the background of this crisis of representation it was precisely this bi-partisan agreement that became the catalyst for the disintegration of Costa Rica's half a century old two-party-system. Whereas the IDB's report on the 'politics of policies' warns of the 'tradeoff between representativeness (or inclusiveness) and policy effectiveness' (ibid: 157), the analysis of the Costa Rican case makes a point quite to the contrary: instead of a trade-off, we found a direct causal link between both. It was precisely the lack of representativeness that crucially undermined the policy's effectiveness.

Although the commitment to liberalization policies brought the political establishment to its most severe crisis and to the brink of electoral defeat, President Arias, in office since May 2006, is determined to continue this course. Again, this insistence will be difficult to explain in a narrowly technocratic perspective on the 'politics of policies'. While the proposal on telecommunications reform as such has been considerably moderated, in the context of the CAFTA agreement it is firmly embedded in a grand project of liberalization, with the corresponding incentives and pressures from the U.S. government and the Washington-based IFIs. As a consequence, as much for the government as for its opponents telecom liberalization becomes, once again, part and parcel of the broader dispute over the country's overall economic orientation.

For many years, Costa Rica and Venezuela had been Latin America's two show-case countries boasting stable political democracies in a troubled continent. Both worked on the basis of an entrenched bi-partisan structure; both began to pursue adjustment policies that became increasingly unpopular; and both came to suffer a severe crisis of representation, aggravated by flaring corruption among the political elite. However, parallels should not be drawn too far. Albeit in crisis, one of Costa Rica's two traditional parties just recently managed to win in clean national elections, even if by a small margin. More importantly still, the challenge to the established party system comes from a very different corner. Hugo Chávez, a military man, condemns the very origin of Venezuela's bi-partisan democracy, the Punto Fijo agreement, as synonym of all political evil. In contrast, Otton Solís has been a senior 
PLN politician for many years and he is challenging the government on what could be called an 'Old PLN' ticket: as a defendant of Costa Rica's long-standing political model which, he claims, the current party leadership is betraying. His party not only acts fully within the established political institutions, it actually is giving them renewed legitimacy and representativeness.

It may well be that both, the PLN and Otton Solís's PAC, can consolidate their electoral appeal and that a new two-party system emerges. But while the bipartisan structure of PLN and PUSC was based on a shared commitment to the same development model, this now is in dispute. If Otton Solís should turn to an increasingly cooperative stance towards the Arias government, he runs the risk not only of alienating his core support groups, but of calling into question the very raison d'être of his political movement. As a result, the current polarization of Costa Rican politics over liberalization means that hardly a return to the type of accomodating bi-partidism is in store that had characterized the country for the past decades. The feedback effects of liberalizing policy reforms have brought this key feature of Costa Rica's long-standing political exceptionalism to an end.

i The term 'telecommunications' encompasses the telephone system as well as other forms of data transmission such as, historically, telegraph, telex or fax, and more recently, of course, the wide array of digital network-based information technologies.

ii The United States was one of the few countries where telecom services were not provided by a public monopoly, but by a private firm, the American Telephone and Telegraph Company (AT\&T). It operated essentially on a monopoly basis, but since the passing of the Communications Act of 1934, it did so within a sophisticated regulatory framework overseen by the governmental Federal Communications Commission (FCC), the world's first stand-alone telecommunications regulator.

iii A significant share of the revenues raised through privatization, however, went into servicing the foreign debt. Argentina, which in 1989 became the second country on the continent to privatize its telecom company, presents an illustrative case: the company was sold solely for debt certificates (Schvarzer 2000: 13). 
iv On the role of the network-based digital information and communication technologies in the drive for telecom liberalizations see Hoffmann 2004.

$\mathrm{v}$ This is confirmed by the country studies in Noam (1998).

vi Author's interview in San José, April 27, 2001.

vii On the crisis and economic policies of the 1980s, see Fürst (1990), Rovira Mas (1989), and Reuben Soto (1988).

viii For a comparative study of telecommunication reform in Rica, Guatemala and Honduras see Bull (2005). The following section draws, aside from the explicitly given references, on numerous interviews by the author during a field stay in Costa Rica in April 2001, a systematic analysis of the country's leading newspaper, La Nación, and the press bulletins of the Legislative Assembly as well as documents of actors involved, in part found in the archives of the Fundación Acceso (San José).

ix The creation of the Sala Cuarta in 1989 had been part of a judicial reform largely supported by the Inter-American Development Bank and meant to foster free market development (Wilson et al. 2004). However, as Wilson et al. point out, its effect on policy-making has not been quite that, and they take the Sala Cuarta's role in the liberalization of telecommunications as a case in point (ibid: 525-527).

$x \quad$ The bill's official name is 'Ley para el mejoramiento de servicios públicos de electricidad y telecomunicaciones y de la participación del Estado'.

xi Besides the three delegates of the left-wing Fuerza Democrática, this was one representative each from the Partido Acción Laborista Alajuelense, the Partido Renovación Costarricense, the Partido Integración Nacional, and the Movimiento Libertario.

xii Within the governing PUSC, it was ex-President Rodrigo Carazo (1978-1982) who led a 'National Citizens' Front' (Frente Cívico Nacional) against the liberalization law and was supported by, amongst others, the social-Christian trade union Confederación de Trabajadores Rerum Novarum.

xiii To save face, the government did not cancel the law altogether, but called for a 60-day freeze to open up a national dialogue. A 'Mixed Commission' (Comisión Mixta) was set up and a broad spectrum of political and social actors invited to discuss and reformulate the bill. However, this was more a conciliatory measure than an actual attempt to produce and implement a new law.

xiv The following draws on one of the President's closest advisors who on the condition of anonymity recounted the political dynamics of the law's withdrawal from the executive's perspective (interview with the author, April 28, 2001 in San José).

$\mathrm{xv}$ It is worth to underscore that the Costa Rican government lacked the option for 'restoring order' by repressive force. The use of the country's police for a large-scale repressive action against non-violent protest with broad public support would have shaken the foundations of the country's political and social system so profoundly that it was excluded. Moreover, the government was well aware of its limited practical ability to implement any such a repressive strategy. In the words of the anonymous Presidential advisor cited above: 'In any other country the government would declare a state of emergency, and if strikes would endanger the national electricity generation, the army would take over the power plants and guarantee at least a minimum of electricity supply. In Costa Rica, however, if the ICE staff refuses to produce electricity, there simply does not exist any other institution which technically would be able to operate it.'

xvi Cf. La Nación, September 11, 2000: 'Desilusión y esperanza en ticos', September 12, 2000: 'Fuerte apoyo a la democracia... pero crítica a los partidos y poderes del Estado', and September 14, 2000: 'Dura crítica a partidos'.

xvii For a more detailed analysis of these initiatives in expanding the digital technologies see Hoffmann (2004: 119-137) and Téramond (2000).

xviii On the corruption scandals and their political implications see Lehoucq 2005, Salom 2005, and Peeler 2006. 


\section{References}

Asamblea Legislativa (2000): Ley para el mejoramiento de los servicios públicos de electricidad y telecomunicaciones y de la participación del Estado. Informe de la Asamblea Legislativa de Costa Rica. La Nación, March 26, 2000.

Bulmer-Thomas, Victor (1987): The Political Economy of Central America since 1920. Cambridge (UK): Cambridge University Press.

Bull, Benedicte (2005): Aid, Power and Privatization: The Politics of Telecommunication Reform in Central America, Cheltenham (UK)/Northampton, MA (USA): Edward Elgar Publishing.

CID Gallup (2005): Public Opinion Survey, 104, July, www.cidgallup.com/archivos/bolcr 104a-ingles.pdf.

Clippinger, John (1976): Who Gains by Communication Development? Studies of Information Technologies in Developing Countries. Working Paper 76-1. Cambridge: Harvard University Press.

Fumero Paniagua, Gerardo (2004): Costa Rica en el marco del TLC y sus consequencias en el área de las telecomunicaciones, en: Flórez-Estrada, María/Hernández, Gerardo (Hrsg.): TLC con Estados Unidos. Contribuciones para el debate, San José, pp. 209-221.

Fürst, Edgar (1990): Politik der Strukturanpassung in Costa Rica, 1982-1988, in: Entwicklungsprobleme Costa Ricas, edited by L. Ellenberg and A. Bergemann. Saarbrücken/Ft. Lauderdale: Breitenbach, pp. 171-194.

Fürst, Edgar/Schmidt, Ernst (ed.) (1986): Demokratie in Costa Rica. Ein zentralamerikanischer Anachronismus?, Berlin: FDCL.

Hoffmann, Bert (2004): The Politics of the Internet in Third World Development. Challenges in Contrasting Regimes with Case Studies of Costa Rica and Cuba. New York: Routledge.

Huhn, Sebastian (2006) Die marode Musterdemokratie Costa Rica, GIGA Focus Lateinamerika, 4/2006, Hamburg: GIGA.

IDB [Inter-American Development Bank] (2005): The Politics of Policies. Economic and Social Progress in Latin America, 2006 Report, Washington DC: IDB.

ITU [International Telecommunication Union] (1984): The Missing Link. Report of the Independent Commission for World Wide Telecommunications Development. Geneva: ITU.

ITU (1991): Restructuring of Telecommunications in Developing Countries. An Empirical Investigation with ITU's Role in Perspective. Geneva: ITU.

ITU (2000): Americas Telecommunications Indicators 2000. Geneva: ITU. 
ITU (2006): World Telecommunication / ICT Indicators Database (CD-Rom, 10th edition), Geneva: ITU.

Lehoucq, Fabrice (2005): Costa Rica. Paradise in Doubt, in: Journal of Democracy 16 (3) 2005, July, pp. 140-154.

Mesa-Lago, Carmelo (2000): Market, Socialist, and Mixed Economies, Comparative Policy and Performance: Chile, Cuba, and Costa Rica. Baltimore: The Johns Hopkins University Press.

Monge, Ricardo (2000): La economía política de un intento fallido de reforma en telecomunicaciones, in: Los retos políticos de la reforma económica en Costa Rica, edited by R. Jiménez. San José: Academia de Centroamérica, pp. 273-318.

Noam, Eli M. (ed.) (1998): Telecommunications in Latin America, Oxford: Oxford University Press.

Peeler, John (2006): Democratic Consolidation and the Changing Significance of Corruption: Costa Rica, Paper delivered at the 2006 Meeting of the Latin American Studies Association, San Juan, Puerto Rico, March 15-18, 2006.

Presidencia de la República (2001): Agenda Digital. Un impulso hacia la sociedad del conocimiento. San José: Presidencia de la República.

Raventos, Pedro (1998): Telecommunications in Central America, HIID Development Discussion Paper. No. 648, Harvard University.

Reuben Soto, Sergio (1988): Ajuste estructural en Costa Rica. Estudio socio-económico de una década. San José: Editorial Porvenir.

Rovira Mas, Jorge (1989): Costa Rica en los años ‘80. 3rd ed. San José: Editorial Porvenir.

Sala Constitucional de la Corte Suprema de Justicia (2000):. Sentencia de Sala Cuarta que declaró inconstitucional el primer debate del ‘Combo ICE' (Exp.: 00-002411-CO-E).

Salom, Roberto E. (2005): Los procesos de corrupción y las perspectivas de la democracia en Costa Rica, in: Nueva Sociedad 196, April/March 2005.

Saunders, Robert J. / Warford, Jeremy J. / Wellenius, Björn (1994): Telecommunications and Economic Development. 2nd ed. Baltimore: The Johns Hopkins University Press.

Schvarzer, Jorge (2000): External Dependency and Internal Transformation: Argentina Confronts the Long Debt Crisis. UNRISD Social Policy and Development Programme Paper 1. Geneva: UNRISD.

Seligson, Mitchell A. (1984): El campesino y el capitalismo agrario de Costa Rica. 2nd ed. San José: Editorial de Costa Rica (Orig. in English as: Peasants of Costa Rica and the Development of Agrarian Capitalism. Madison: University of Wisconsin Press, 1980). 
Seligson, Mitchell A. (2002): Trouble in Paradise? The erosion of system support in Costa Rica, 1978-1999. Latin American Research Review, Vol. 37, No. 1, pp. 160-185.

Téramond, Guy de (2000): Transcript of Interview, January 6, 2000, in: Fundación Acceso (ed.): Regulación y uso de las nuevas tecnologías de información y comunicación (NTIC): El caso de Costa Rica. San José: Fundación Acceso, pp. 84-86.

UNDP (2006): Human Development Report 2006, Oxford / New York: Oxford University Press.

Unimer-La Nación (2000): Manifestaciones Sociales [Encuesta sobre el Combo del ICE]. www.nacion.co.cr/ln_ee/encuestas/unimer/6-2000/parte7.htm. Summary in: La Nación, June 25, 2000.

Whitehead, Laurence (2006): Privatization and the Public Interest: Partial Theories, Lopsided Outcomes, in: Whitehead, Laurence: Latin America. A New Interpretation, New York: Palgrave, pp. 163-194.

Williamson, John (1990): What Washington Means by Policy Reform, in: Latin American Adjustment. How Much has Happened?, by John Williamson. Washington DC: Institute for International Economics, pp. 7-20.

Wilson, Bruce (1994): When Social Democrats Choose Neoliberal Economic Policies: The Case of Costa Rica, in: Comparative Politics 26 (2), pp. 145-168.

Wilson, Bruce (1998): Costa Rica: Politics, Economics, and Democracy. Boulder: Lynne Rienner Publications.

Wilson, Bruce / Rodríguez Cordero, Juan Carlos / Handberg, Roger (2004): The Best Laid Schemes... Gang Aft A-Gley: Judicial Reform in Latin America-Evidence from Costa Rica, in: Journal of Latin American Studies 36 (3), pp. 507-531. 


\section{G

\section{Recent issues:}

No 46 Sonja Bartsch and Lars Kohlmorgen: The Role of Southern Actors in Global Governance: The Fight against HIV/AIDS; March 2007

No 45 Gero Erdmann: Ethnicity, Voter Alignment and Political Party Affiliation - an African Case: Zambia; March 2007

No 44 Andreas Ufen: Political Party and Party System Institutionalisation in Southeast Asia: A Comparison of Indonesia, the Philippines, and Thailand; March 2007

No 43 Alexander Stroh: Crafting Political Institutions in Africa. Electoral Systems and Systems of Government in Rwanda and Zambia Compared; March 2007

No 42 Günter Schucher: The EU's Foreign Policy after the Fifth Enlargement: Any Change in Its Taiwan Policy?; February 2007

No 41 Henriette Dose: Securing Household Income among Small-scale Farmers in Kakamega District: Possibilities and Limitations of Diversification; February 2007

No 40 Gero Erdmann and Matthias Basedau: Problems of Categorizing and Explaining Party Systems in Africa; January 2007

No 39 Jutta Hebel and Günter Schucher: The Emergence of a New 'Socialist' Market Labour Regime in China; December 2006

No 38 Barbara Fritz and Laurissa Mühlich: Regional Monetary Integration among Developing Countries: New Opportunities for Macroeconomic Stability beyond the Theory of Optimum Currency Areas?; December 2006

No 37 Andreas Ufen: Political Parties in Post-Suharto Indonesia: Between politik aliran and 'Philippinisation'; December 2006

No 36 Juliane Brach: Ten Years after: Achievements and Challenges of the Euro-Mediterranean Economic and Financial Partnership; December 2006

No 35 Christian von Soest: Measuring the Capability to Raise Revenue. Process and Output Dimensions and Their Application to the Zambia Revenue Authority; December 2006

No 34 Sebastian Huhn, Anika Oettler and Peter Peetz: Construyendo Inseguridades. Aproximaciones a la violencia en Centroamérica desde el análisis del discurso [Constructed insecurities. Discourse analysis and the understanding of violence in Central America]; November 2006

All GIGA Working Papers are available free of charge at www.giga-hamburg.de/workingpapers. For any requests please contact: workingpapers@giga-hamburg.de.

Editor of the Working Paper Series: Bert Hoffmann. 